\title{
Investigating the Revival of Ancient Egyptian Artifacts as a Symbol of Power through their Occupation of European Public Spaces: A Chrono-Morphological Study
}

\author{
By Mohamed Raslan ${ }^{*}$ István Bartók ${ }^{ \pm} \&$ Zoltán Szécsi
}

\begin{abstract}
Numerous architectural styles have been explored in recent years (Pakkanen 2018). However, Egyptian revival did not obtain the consideration it deserved till lately, when there was a remarkable flow of attention coursed by various significant ancient Egyptian exhibitions all over the world, which led to the publications of books and articles tackling the Egyptian revival (Curl 2013). In this paper the researcher will try to investigate the chronological change of form and shape of ancient Egyptian architectural features that were revived in European public spaces to signify power, sovereignty, and authority. Curl (2013) charts the argument of the persistence of Egyptian motifs in design from GrecoRoman Antiquity, through the Mediaeval, Baroque, and Neo-Classical periods. Our hypothesis is that Ancient Egypt is a central source, rather than peripheral, to the development of considerable volume of European urbanistic and architectural features. We will distinguish manifestations with Egyptian connotations based on literature reviewed, field observation and the methodology of Curl (2013). Aiming only on three ancient Egyptian sources, the Sphinx, the obelisk, and the temple.
\end{abstract}

Keywords: Egyptian revival, Ancient Egyptian artifacts, morphological regeneration, space occupation, public spaces

\section{Introduction}

The civilization of the West that progressed from the Greco-Roman realm, later from the intricate organization of the Christian Church and its direct connections with secular power and the legitimizing of that power, depicted profoundly on the religion of Ancient Egypt and the authority given to religion people of the Pharaoh, a statement that is often overlooked, or proclaimed as 'extravagant' by reviewers (Curl 2013).

It is acknowledged that trading interactions between Egypt and the Greek realm were ascertained from the latter half of the second millennium BC and the Greek obtained settlements in Egypt from around the seventh century BC (Stevens 2020). Herodotus journeyed to Egypt had produced an exceptionally appreciated interpretation in his narrations, which were afterwards viewed as prime sources by later authors (Innis 2008). The Greeks were attentive of the antiquity of Egypt and

\footnotetext{
*Assistant Lecturer, Budapest University of Technology and Economics, Hungary \& Alexandria University, Egypt.

${ }^{ \pm}$Lecturer, Budapest University of Technology and Economics, Hungary.

Lecturer, Budapest University of Technology and Economics, Hungary.
} 
were captivated by its religion and buildings (Bishop 2015). More essentially, was the esteem with which Egypt was alleged, as it was realized as the source of all ancient wisdom (Tomorad 2019).

This superiority or better say precedence of the ancient Egyptian antiquity, can be decoded and observed in many European illustrations of art and architecture across history (Bowdler 2006). In this paper, we will shortly mention three sources of influence translated into power symbolism, which are the sphinx, the obelisk, and the temple. We will then decode how they evolved in terms of space occupation.

\section{Methodology}

The paper presents a brief of the development of the three chosen Ancient Egyptian architectural features, by providing a morphological analysis of these features through the selected case studies. The examples are organized through a chronological order, and then investigated through the lens of their historical space occupation development.

Future studies can further investigate the impact of Egyptian revival in other parts of the world, utilizing the same methodology adapted. Additionally, the impact of Egyptian revival in Europe upon adaption by modern Egypt is a relatively untouched topic which can be of interest.

\section{The Sphinx}

The Lion was always associated with power since early civilizations (Ball 2018). The king of outside statues was originally used in ancient Egypt when carved stone sphinxes (statues of a lion's body with a human head) lined the road from Karnak to Luxor in Egypt. Noticeably in China, guardian lions have been prevalent from the time when the Han Empire was flourishing, but that was way after the Egyptians. The earliest example for the use of a pair of lions as guardian statues placed on both sides of an entrance was the Prudhoe lions of the temple of Soleb in Nuba Egypt (see Figure 1).

Ancient Egyptians had three types of sphinxes, Crisophinx (lion body with ram head), Hierocosphinx (lion body with hawk head), and Androsphinx (lion body with human head, like the Great Sphinx) (Curl 2013). The Great Sphinx was believed to stand as a guardian of the Giza Plateau, where it faces the rising sun. It was the focus of solar worship in the Old Kingdom. It was also considered the optimal image of the power and fearsome of the pharaoh (Osborne 2014).

This guardian sphinx evolved across time into the guardian lions throughout the Roman Empire and then revived in the renaissance and later from the eighteenth century it was used in various buildings resembling power, which was elaborated in detail by (Riad and Jack 2020). 
Figure 1. A Chronological Study of the Development of the Lion Statue

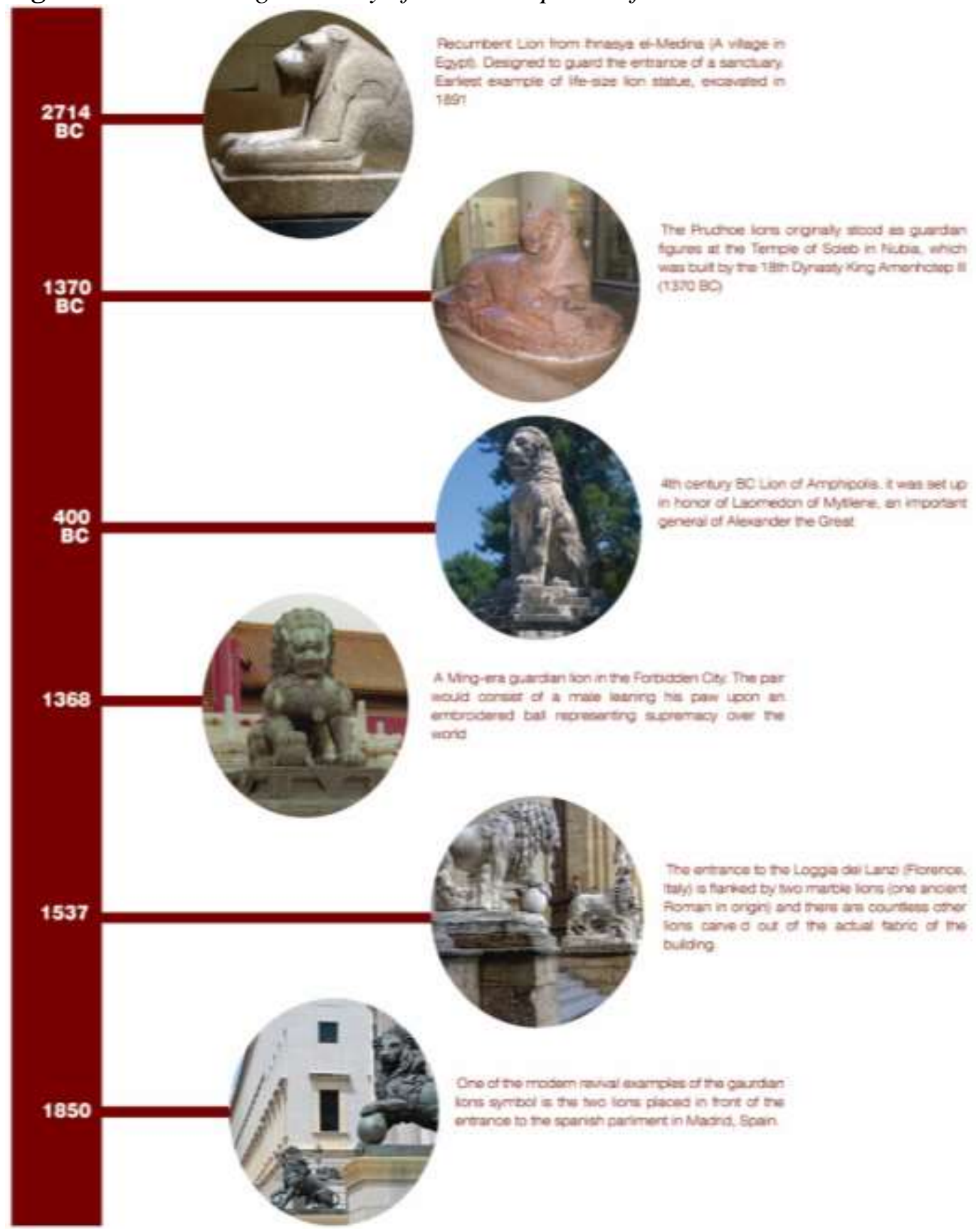

Source: Authors.

We can argue that the lions standing pridefully alongside the entrance of the Hungarian parliament, is a representation of power and authority more than being guardians, due to the posture of the lions. Another example is the palace of justice in Sofia, Bulgaria where the lions there are in a walking stand while raising their heads. This pair of lions can be seen in front of various remarkably important buildings in European cities. Odenonsplatz in Munich, Spanish Parliament of Madrid, Cantacuzino Palace in Bucharest, Kolomenskoye in Moscow and armed lions of Town hall in Lviv. 
Mostly, these buildings are governmental or administrative buildings and the connection with authority and power is always relevant. It can be even interesting to study a map of the guardian lions with their posture across European cities and why did each architect choose to put those lions.

\section{Space Occupation Development of the Sphinx}

The earliest usage of sphinx statue on the sides of honorary stairs or ramp, was situated in the Hatshepsut temple 1458 BC (Luxor, Egypt). As an approach for the stairs, two or three rows of sphinxes were used, however the two statues define the space of the stairs were exactly in the beginning of the stairs. The two statues were oriented as their backs are facing the temple and their faces welcoming the visitors or rather declaring the dominance of the space to come behind them. It was not the first use of these statues as guardians to a sacred place, since the recumbent lion is the most ancient (Riad and Jack 2020).

Next comes the renowned Karnak temple relates to the Luxor temple with a two kilometers avenue of sphinxes. The sphinxes were oriented facing the honorary avenue on both sides and defining the space which the avenue is occupying through close repetition (see Figure 2).

Forward to the renaissance, in villa Medici 1598 (Florence, Italy), the lions' statues were on both sides of the entrance. However, their orientation was that their sides were in line with the facade of the villa, which interpreted as defining part of the facade (a decoration) rather than guarding the space.

Unlike all other examples, the four lions' statues in Trafalgar square 1844 (London, UK) were oriented towards true directions (North, South, East and West). They were created in the guardian position, and their orientation was to symbolize dominance in all directions. However, this pattern of four directional lions or sphinxes guarding a vertical element was designed before in Place du Chatelet 1802 (Paris, France) and in Piazza del Popolo 1822 (Rome, Italy). Yet, the English examples stood out because of the significance of orienting to the true directions.

Although Ancient Egypt was the first civilization to use the sphinx (lion) statue to symbolize power or guardianship, the statue was further developed throughout history with additions from different cultures. The materials used, the level of details, the statues orientation and their posture are among many features which have changed across time. 
Figure 2. Space Occupation Diagram Demonstrating the Differences in the Methods of Allocating the Lion (Sphinx) Statue in Space

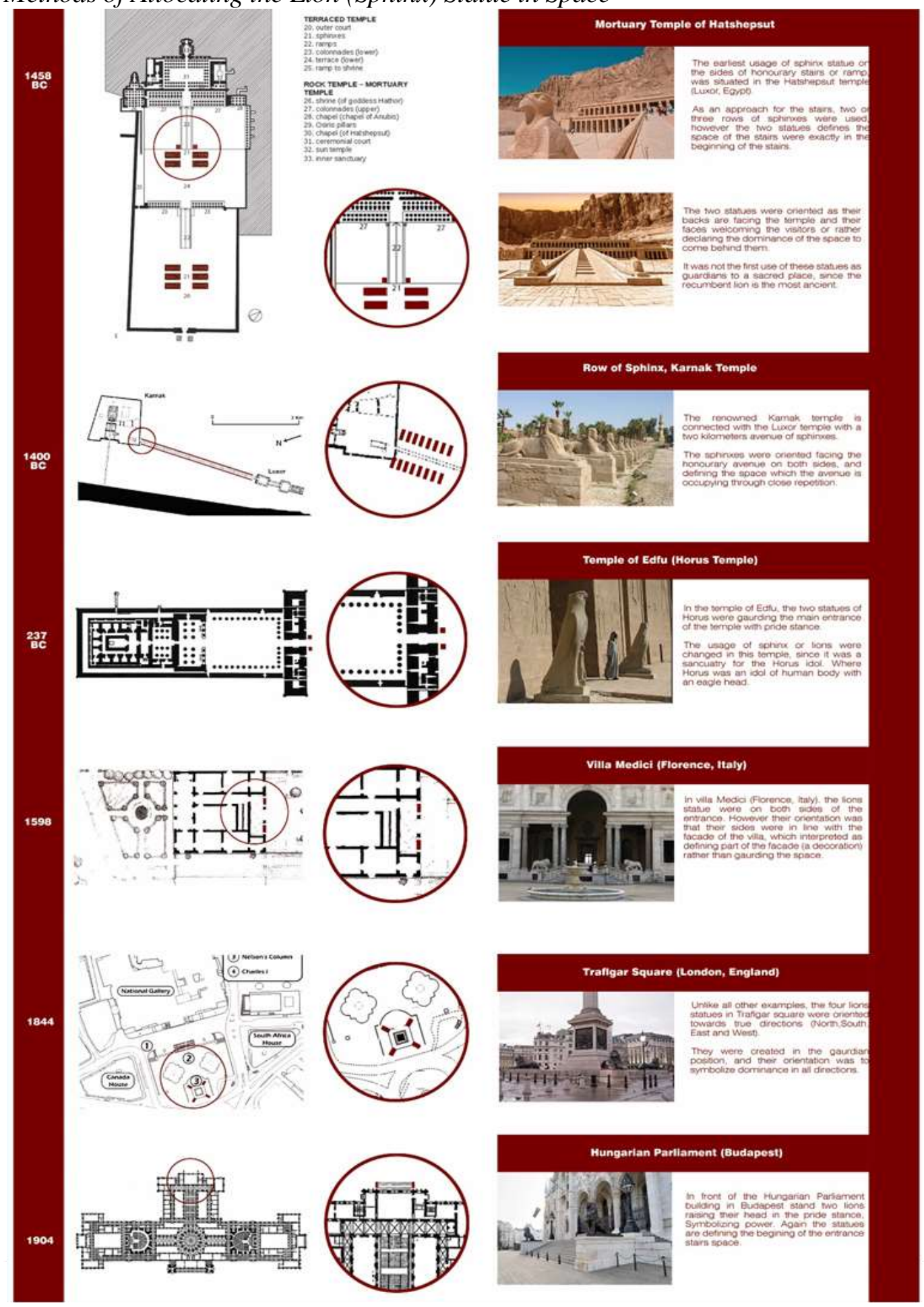

Source: Authors.

Even if Egypt inspired Europe in the beginning, the opposite happened in modern times. In the $19^{\text {th }}$ century, the European advancement in all fields was a 
reason for Egyptian architects to get inspirations from successful European landmarks. A good example is the chain bridge (Budapest, Hungary) that was established to connect the two cities across the Danube, Buda and Pest. The bridge was decorated by placing two lions in the guardian position in both its ends, which was imitated in designing Kasr EL-Nile Bridge connecting the two banks of the Nile River in the very heart of Cairo (see Figure 3).

Figure 3. The Resemblance between the Chain Bridge in Budapest and Kasr El-

Nile Bridge in Cairo

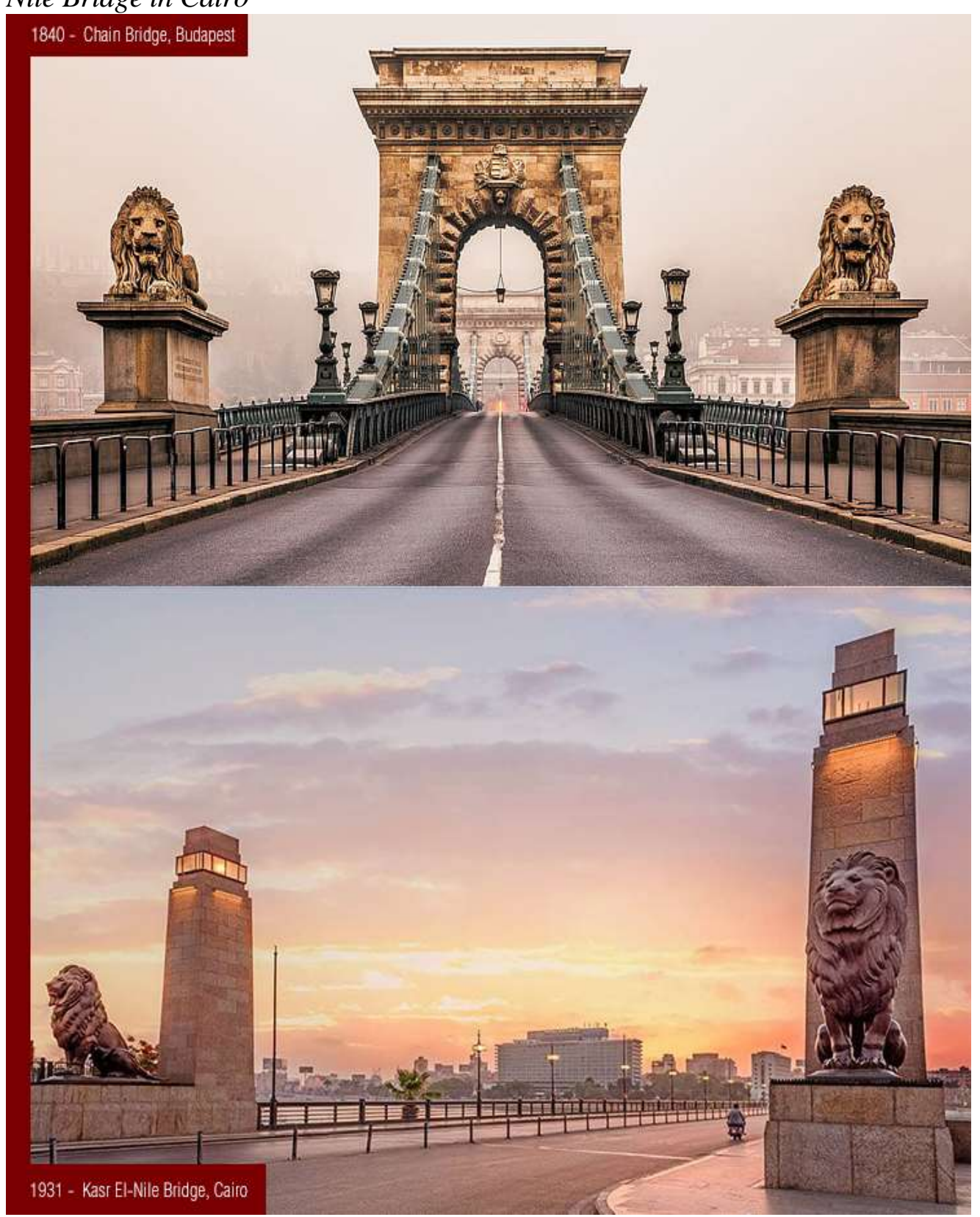

Source: Authors. 


\section{The Obelisk}

The first usage of a singular vertical element as a memorial was the obelisk of Luxor temple in Egypt. The obelisk is of yellow granite and inscribed with hieroglyphs in honor of the Pharaoh Ramesses II. The Egyptian artifact was revived in ancient Rome in the form of the Trajan's-column which commemorated Roman Emperor Trajan's victory in the Dacian Wars (Kahn 2014). The statue of St. Peter's was added in 1587. Later the obelisk had taken many evolutionary transformations or abstraction and is found placed in multiple sites across Europe (see Figure 4).

Figure 4. The Chrono-Morphological Development of the Obelisk in Europe

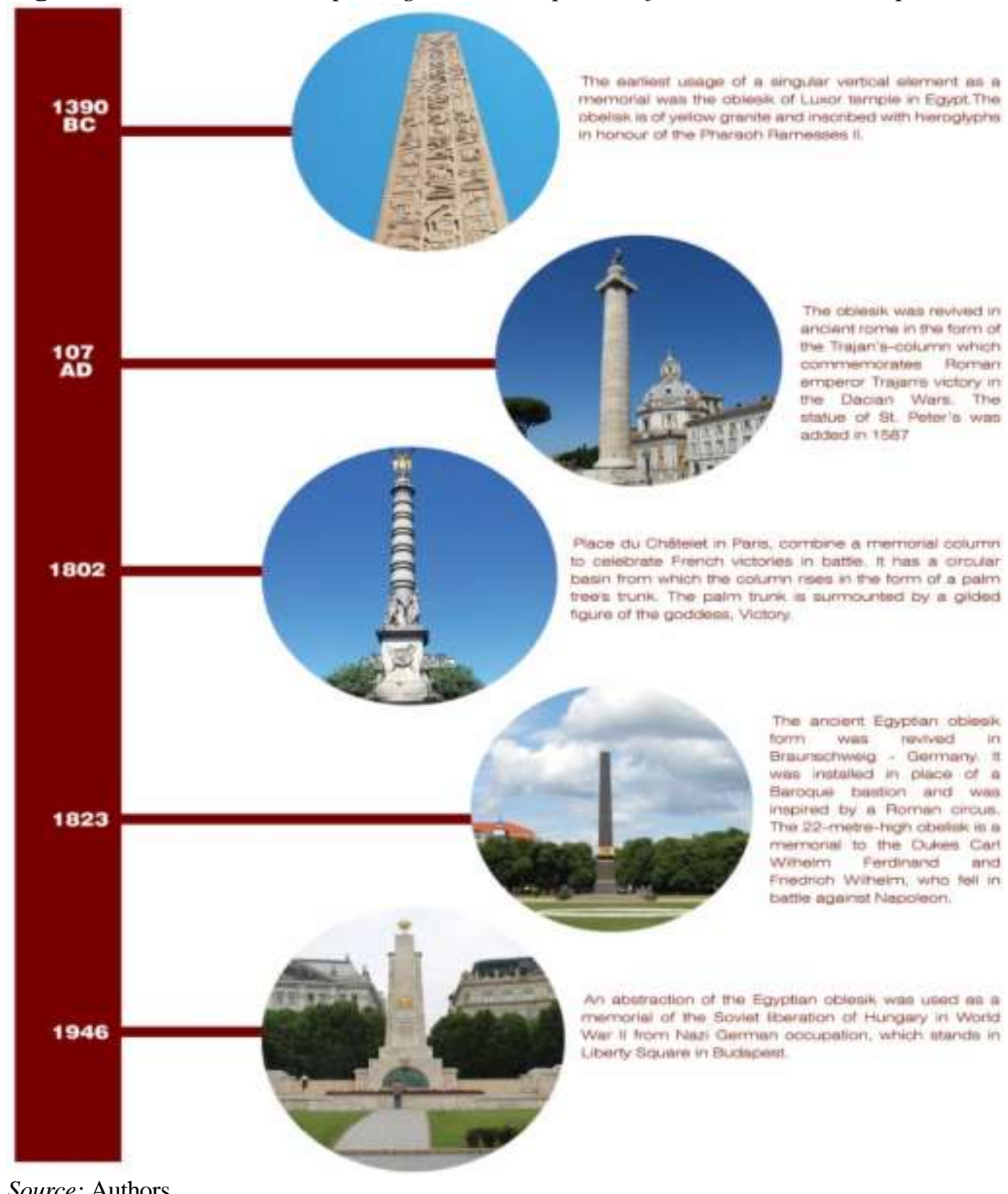


It is distinct that Egyptian artifacts were of immense importance during the Roman Empire. The many obelisks that grace the squares and open spaces of Rome itself, for example, provide evidence of the esteem in which these Egyptian objects were held in imperial times (although they have only stood on their present sites from the Renaissance and Baroque periods) (Ball 2018). The collections of Egyptian pieces and of Roman works in the Egyptian style in the Vatican and Capitoline Museums indicate how widespread were such objects during the Roman Empire, and study of the literature dealing with the sites where ancient artefacts were discovered reveals that Egyptian cults had a powerful influence in imperial Rome (Osborne 2014).

Weststeijn (2018) tried to gather all the ancient Egyptian obelisks locations and history of transferring, where he found that there are nearly 70 obelisks, nearly half of this number was transferred to Europe across history. And based on what we mentioned in the previous paragraph, it is of no surprise that 20 obelisks are in Italy, yet 12 of them in Rome, the capital of the Roman Empire. Remarkably in Egypt there are only 11 obelisks remaining (Stevens 2020).

It is hardly surprising that, as the obelisks in Rome were unearthed, investigated, re-established, or moved to positions of distinction, they stimulated extensive attention. The excessive number of engravings of obelisks and columns in the Cinquecento affirms to the significance given to those Antique objects, and the fine fresco in the Vatican Library shows how those obelisks dominate the plan (Curl 2013).

Emperor Sixtus and his architects allocated obelisks at points where glorious urban spaces would be established, so the center pieces of principal public areas, in addition to the focal-points or landmarks of streets, were Egyptian obelisks (Childress 2019). Later of course, the catholic church Christianized the obelisk by putting a cross on top of it, nevertheless the obelisks remained standing in the center of the most valuable piazzas in Rome like, Piazza del Popolo, Piazza di San Giovanni in Laterano, Piazza Navona, Piazza della Rotonda (in front of Pantheon) and many other significant areas. However, the arguably most vital one is in Vatican City, Piazza San Pietro (St. Peter's Square), in front of the most powerful church in the world and location of the obelisk in the center of the piazza is affirming the influence of centrality and power (Ristic 2020).

\section{Space Occupation Development of the Obelisk}

Although Ancient Egyptians used the obelisks mainly in pair, they used them as a portal or an approach to their temples, where they placed a memorial about the signified god or pharaoh along the writings engraved on the obelisk (Mitchell 2012). Spatially they were used in pair to define the main axis between them. Nevertheless, they never located them in the center of a space (Abdelwahab 2018).

On the other hand, the romans were the first to erect the Egyptian obelisks in the center of their public spaces (piazza) and this center is most of the times defining the main access to the space. So, their use of obelisks could be interpreted 
to define centrality and axiality. Later other European urban designers adopted the roman model of the obelisk placement (see Figure 5).

Figure 5. An Illustration of the Development of the Axiality and Centrality of Public Spaces Enclosing an Obelisk

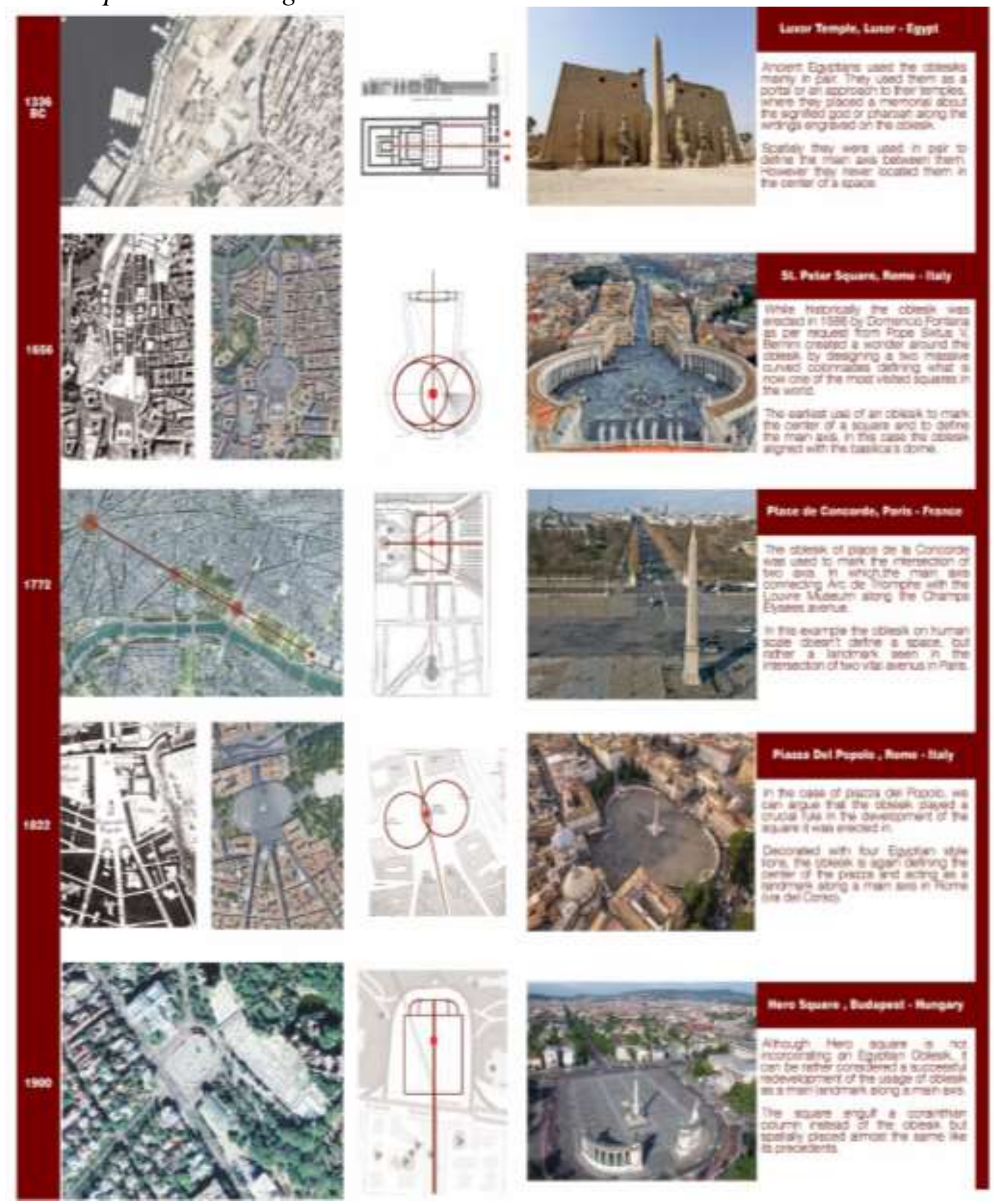

Source: Authors.

Ancient Egyptians never intended to use the obelisk with such dramatic significance to pinpoint the center of the most important (power signifying) public spaces, rather used them as portals or memorials. However, the romans revived the usage of obelisks as memorials by their renowned Trajan's column which commemorates Roman Emperor Trajan's victory in the Dacian Wars. Besides erecting transported Egyptian obelisks to their most vital squares. This movement 
was the start of a trend for European capitals to utilize Egyptian obelisks or one of their developed or abstracted phases named as the memorial column to be placed as a landmark on the main axis leading to a public space.

\section{The Temple}

Innis (1964) addresses the question of the political and propagandistic use of architecture through history. The rise and decline of empires, Innis believed, are due to the failure to consolidate control. A reliance on military or on technological improvements were options, but a more permanent method, Innis believed, was architecture. The Gothic cathedrals of Europe, another example of architectural control, were obvious reminders, to the masses, of the power of the Catholic Church, and of architecture as a form of political control. The stone used in early architecture, like the Egyptians, emphasized permanence and durability, and created recognizable and lasting reminders of the power and glory of the builders, especially clear in the stone temples in Luxor. Innis looked to the Egyptians for the best example and writes, "the pyramids, reflected the power of a far reaching and comprehensive centralization by a controlling mind".

In 1941, Hitler approved that ancient Rome had been his motivation for his building plans. Demanding that granite should be used on the construction projects, he anticipated that they would last 4,000, or perhaps even 10,000 years, and rival Roman ruins (Narver 1986).

Narver (1986), in his discussion of the similarities between Nazi Germany and Imperial Rome, wrote that the Roman empire was a military state based on bombast, superstition and terror, with torture, mutilation and execution; in short, a society of spectacle. In their ordered cruelty, he continued, and in their selfjustifying through myth, ceremony and monuments, Europe's fascist movements expressed the entrenched values of the Romans. When the Nazis adopted neoclassical style, he concluded, they had a right to do so; they were among the heirs of Rome. Temples of Egypt also held special significance for Hitler. These large and long-lasting man-made structures contained desirable elements which German architects were expected to duplicate, for centuries to come.

The temple of Horus in Edfu, for instance, has inspired the design of Propyläen (city gate) standing as the most remarkable entry to the Nazi plaza of Königsplatz in Munich (see Figure 6). While the city gate is mainly of neoclassical style with Doric order, we can argue that the two towers on the side of the gate, is a clear representation of influence from the temple with its side pylons. 
Figure 6. A Chronological Assortment of Buildings of Different Architectural Styles Inspired by an Egyptian Temple

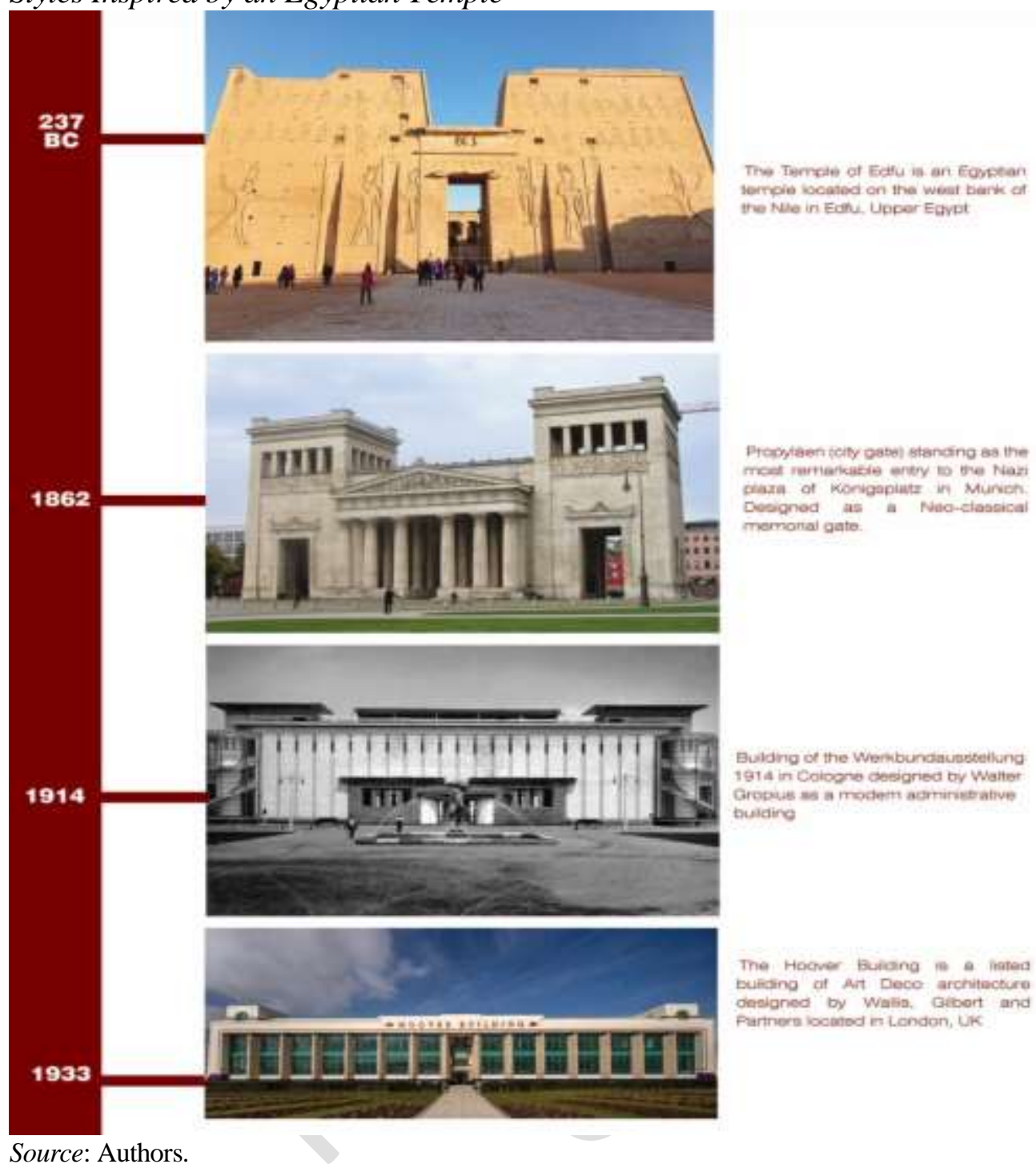

The temple of Horus also inspired the renowned Walter Gropius (18831969). Images of his distinguished building (designed in fellowship with Adolf Meyer) at the Deutscher Werkbundausstellung, Köln (1914), usually show the symmetrical facade edged by rounded staircases. Nonetheless, on both sides of the main entrance are windows segmented by similar square columns derivative from Ancient Egyptian architecture, whereas overhead the blunt monotonous front mount two pylon forms. Which is mostly not revealed in the plan of the building, which has staggering similarities to the temple of Horus and a reconstruction of that temple was shown at an exhibition in Berlin in 1896, which Gropius may have seen (Curl 2013). 


\section{Discussion}

We can argue that the ancient Egyptian style have influenced many architectural styles throughout history. Curl (2013) argued that the ancient Egyptian style have deeply influenced the Greek and the roman architecture with the rows of huge columns and beams. However, we can also assert that it was also revisited in the renaissance era and later in the Eastern-European (soviet) totalitarian regimes, too, through the aesthetics of them, the so-called social realism as the latest manifestation of the revival in the twentieth century. The most recent appearance might exist in the West (USA and Europe after 1970s) in the post-modernism era, but it was a plain mimicry without heavy political symbolism behind, regarded as just an illustration of the consuming society.

\section{Conclusion}

Throughout history, ancient Egyptian architecture has evolved and revived in various forms and styles. Some can even argue that it is hardly identifiable, that the later phases or transformation of the first Ancient Egyptian features, have clear resemblance to its source (see Figure 7). Nevertheless, through a chronological tracing of each phase of development, we can clearly identify the morphological steps.

Furthermore, since many of the most dominating architecture features like the sphinx, the obelisk and the temples were used in ancient Egypt to resemble power and prominence, these features can be identified again in European cities and buildings where the buildings are striving to signify distinction of power.

It became clear to the researcher that, in future studies, we can further investigate the impact of Egyptian revival in other parts of the world, utilizing the same methodology adapted. The adaption of modern Egypt to the European Egyptian revival was very briefly mentioned in this paper discussing the case of resemblance between the Chain bridge in Budapest and Kasr El-Nile Bridge in Cairo. However, it can be further analyzed on more levels rather than just resemblance and employing other study lenses just as we utilized space occupation in this research. 
Figure 7. An Illustration of the Argumentation that Transformations are Difficult to Link to their Source

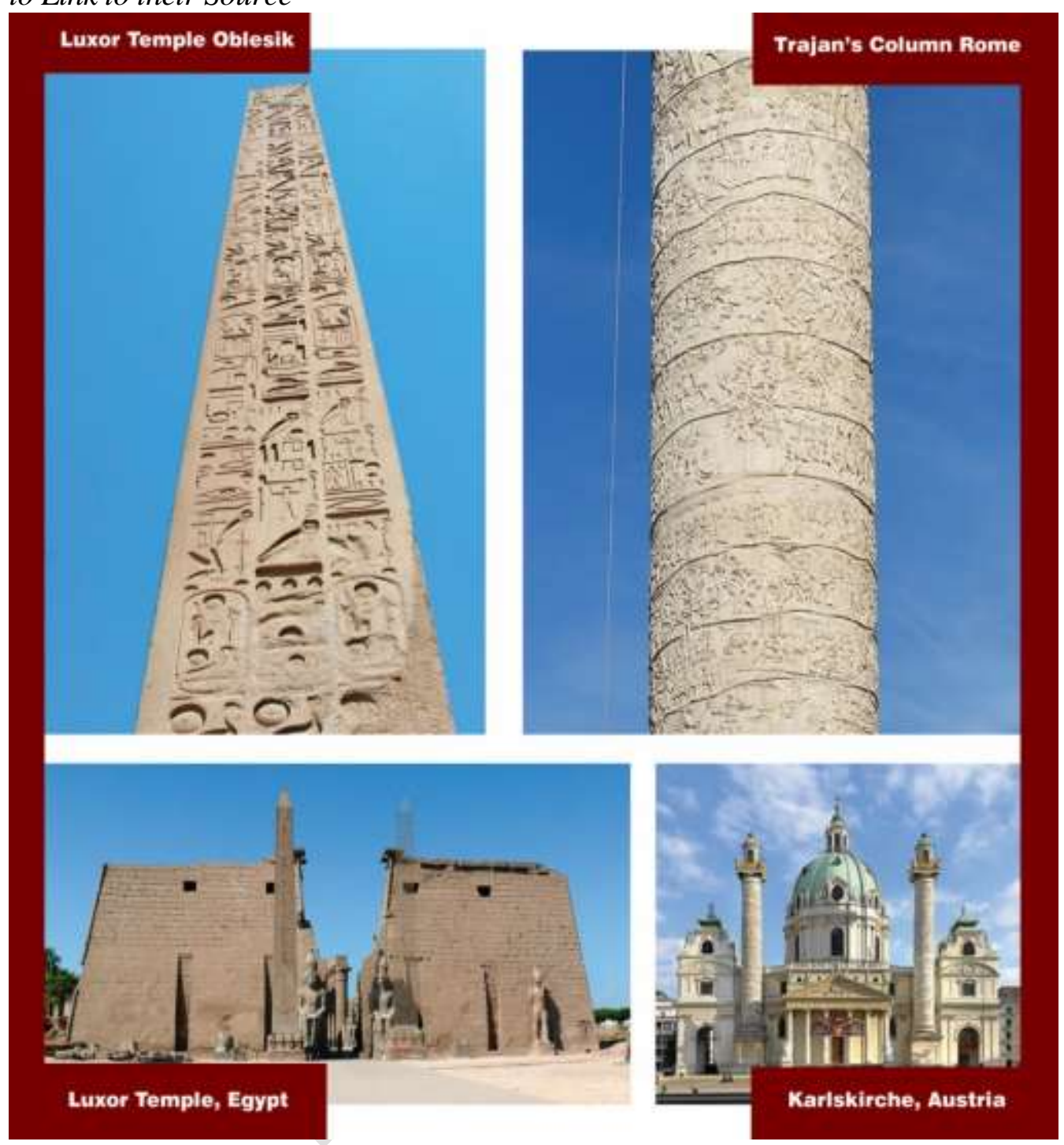

Source: Authors.

\section{References}

Abdelwahab MA (2018) A reflexive reading of urban space. London: Routledge.

Ball J (2018) Staging of memory: monuments, commemoration, and the demarcation of Portuguese space in colonial Angola. Journal of Southern African Studies 44(1): 7796.

Bishop P (2015) Book review: Michael Minkenberg (Ed.): Power and architecture: the construction of capitals and the politics of space. Journal of European Studies 45(1): 66-67.

Bowdler R (2006) The Egyptian revival: ancient Egypt as the inspiration for design motifs in the West. By Curl JS. The Antiquaries Journal 86: 461-462.

Childress D (2019) Obelisks: towers of power: the mysterious purpose of obelisks. New York: Adventures Unlimited Press. 
Curl JS (2013) The Egyptian revival: ancient Egypt as the inspiration for design motifs in the West. London: Routledge.

Innis, H. A. (2008). The bias of communication. University of Toronto Press.

Kahn J (2014) Approaching monumentality in archaeology. Edited by JF Osborne. Albany: State University of New York Press.

Mitchell WJ (2012) Image, space, revolution: the arts of occupation. Critical Inquiry 39(1): 8-32.

Narver DJ (1986) The cultural production of domination in Nazi Germany: architecture as propoganda. Toroto: Simon Fraser University Press.

Osborne WR (2014) The tree of life in ancient egypt and the book of proverbs. Journal of Ancient Near Eastern Religions 14(1): 114-139.

Pakkanen P (2018) Termini. Cornerstone of modern Rome. In A Weststeijn, F Whitling (eds.), Opuscula. Athens and Rome: Annual of the Swedish Institutes.

Riad S, Jack G (2020) Tracing the Sphinx from symbol to specters: reflections on the organization of geographies of concern. Culture and Organization (Oct). DOI: 10.10 80/14759551.2020.1830284.

Ristic SF (2020) Urban fallism: monuments, iconoclasm and activism. City 24(3-4): 552564.

Stevens Q (2020) Cities and memory: a history of the role of memorials in urban design from the Renaissance to Canberra. Planning Perspectives 35(3): 401-431.

Tomorad M (2019) Egypt in Croatia: Croatian fascination with ancient Egypt from antiquity to modern times. Archaeopress Archaeology. 